\title{
Making Ritual Strange: The Temple Cult as the Foundation for Tannaitic Discourse on Idolatry
}

Avram R. Shannon

Brigham Young University - Provo, avram_shannon@byu.edu

Follow this and additional works at: https://scholarsarchive.byu.edu/facpub

Part of the Biblical Studies Commons, and the Other Religion Commons

\section{Original Publication Citation}

“Making Ritual Strange: The Temple Cult as the Foundation for Tannaitic Discourse on Idolatry," Jewish Studies Quarterly 24/4 (2017): 339-355

\section{BYU ScholarsArchive Citation}

Shannon, Avram R., "Making Ritual Strange: The Temple Cult as the Foundation for Tannaitic Discourse on Idolatry" (2017). Faculty Publications. 4310.

https://scholarsarchive.byu.edu/facpub/4310

This Peer-Reviewed Article is brought to you for free and open access by BYU ScholarsArchive. It has been accepted for inclusion in Faculty Publications by an authorized administrator of BYU ScholarsArchive. For more information, please contact ellen_amatangelo@byu.edu. 


\section{Jewish Studies}

\section{Quarterly}

Volume 24 Rachel Neis

No. 4

The Reproduction of Species: Humans, Animals

2017 and Species Nonconformity in Early Rabbinic

Science 289-317

Daniel H. Weiss

Born into Covenantal Salvation?

Baptism and Birth in Early Christianity

and Classical Rabbinic Judaism 318-338

Avram R. Shannon

Making Ritual Strange: The Temple Cult as the Foundation for Tannaitic Discourse on Idolatry $339-355$

Nathaniel Berman

Demonic Writing: Textuality, Otherness and Zoharic Proliferation 356-386 
Avram R. Shannon

Brigham Young University, USA

\title{
Making Ritual Strange: The Temple Cult as the Foundation for Tannaitic Discourse on Idolatry*
}

\begin{abstract}
This article examines the Tannaitic conception of the worship of avodah zarah. The term is commonly translated as "idolatry," but the definition of what constitutes worship of avodah zarah, in m. Sanh. 7:6, is based on a more nuanced notion than simply worship of foreign gods. For the Sages of the Mishnah, worship of avodah zarah involved misuse of objects and rituals associated with the Temple cult, which constituted a betrayal of covenantal loyalty. This means that although the rabbinic laws against the worship of avodah zarah were based on the biblical prohibitions against worshiping other gods, the actual rules for how these laws were to be enacted were extrapolations of the laws against the misuse of Temple objects. This explains why some activities that might seem like idolatry - such as decorating a cult statue or dedicating a child to Molech - are not considered avodah zarah.
\end{abstract}

Key words: idolatry, avodah zarah, covenantal loyalty, Mishnah.

\section{Introduction}

This article examines the nature of the Tannaitic conception of the worship of avodah zarah, commonly translated as "idolatry," showing that the Jews of the Tannaitic period, as represented in the Mishnah and Tosefta, did not have a separate category for non-Jewish ritual. Instead, their conception comprised a category that was applied to both Jewish and non-Jewish ritual. This ritual notion may be conveniently thought of as a broad category of avodah. The source for this broad category, and therefore for Tannaitic notions on both Jewish and non-Jewish ritual, was the Temple cult centered in Jerusalem and the various scriptures adduced to describe it. From the Tannaitic perspective, the difficulty with non-Jewish ritual was not that it was something wholly different from Jewish ritual, but instead that it was

* A version of this paper was presented at the 37th Annual Conference of the Association for Jewish Studies in Boston, Massachusetts. The author is thankful for the comments there, as well as those from Andrew C. Smith, Michael Swartz, Daniel Frank and the anonymous reviewers for this journal.

1 W. A. L. Elmslie, The Mishna on Idolatry (Cambridge: Cambridge University Press, 1911; repub. Wipf and Stock, 2004) xxii-xxiv; E. E. Urbach, "Rabbinical Laws of Idolatry in the Second and Third Centuries in the Light of Historical and Archaeological Facts," Israel Exploration Journal 9 (1959) 149-65, 229-45. 
all too similar. Because of this similarity, the Sages built a discourse that focused on those places where they could find a plausible context for ritual. The Tannaitic discourse on non-Jewish ritual did not center on the temples and cults of the Greco-Roman world, but on places where there were plausible ritual interactions between Jews and non-Jews, such as fairs and the pouring of libations. Because the Sages' ritual notions were focused on the Temple, the possibility of such rituals being performed in other places where Jews might take part was a major driving force in how the Tannaitic Sages legislated about the Temple.

Indeed, the Temple is the category through which the Tannaitic Sages understood ritual. Although Tannaitic Judaism is largely a post-Temple system, the Temple is everywhere absent. ${ }^{2}$ Naftali Cohn has shown that the Sages use the Temple in order to illustrate and solidify their leadership over other parts of Judaism. ${ }^{3}$ He argues that the rabbis of the Mishnah present detailed ritual narratives ${ }^{4}$ about the Second Temple in order to establish themselves as Roman-style jurists over Jewish ritual law, including and especially Temple law. ${ }^{5}$ Thus, being experts in Temple law, which means ritual law, the Mishnah gives the Sages authority over all aspects of Jewish life. This central emphasis on the rituals of the Jerusalem Temple means that the Temple ideas pervade Tannaitic law, even in areas that are directly opposed to the Temple, such as non-Jewish ritual and religious practices, called avodah zarah by the Sages.

Even in its discussion of non-Jewish ritual, the Mishnah is not generally concerned with foreign ritual narratives. ${ }^{6}$ The regulation of proper performance of non-Jewish ritual would be outside the jurisdiction of the Sages in any case. In spite of this, the Tannaitic Sages apply categories deriving from their own rituals to non-Jewish ritual. The presence of detailed descriptions

2 Jacob Neusner, "Map without Territory: Mishnah's System of Sacrifice and Sanctuary," History of Religions 19 (1979) 103-127, 110-12. Jonathan Klawans, Purity, Sacrifice and the Temple (Oxford: Oxford University Press, 2005) 198-202.

3 Naftali S. Cohn, Memory of the Temple (Philadelphia: University of Pennsylvania Press, 2012).

4 Cohn uses the term "Temple ritual narratives" to describe the form of those parts of the Mishnah that are dedicated to describing the rituals of the destroyed Jerusalem temple. He identifies four generic features of these ritual narratives: 1 ) a mix of tenses refer to past action; 2) the narratives are sequential, even though they sometimes lack some characteristics of "narrative" as such; 3) they use distinctive set phrases; and 4) they use "how so?" (ketzad) as an introductory formula. See Cohn, Memory, 4-11.

5 Cohn, Memory, 119-20.

6 This is entirely in keeping with Cohn's thesis that the Mishnah represents the Sages establishing their leadership through creating memories of a ritual system that was beholden to them for its proper regulation. 
of Temple ritual in Mishnah underscores their claim to being ritual experts over the Temple, something which is continued in Tosefta and the Tannaitic midrashim. ${ }^{7}$ Although the Temple was destroyed, it was at the core of the Tannaitic discussion on ritual. Their conception of ritual was one that, therefore, that extended their conceptions of ritual into universals. ${ }^{8}$

I look at how the Sages of the Mishnah deploy and understand the worship of avodah zarah. While this collocation literally means "foreign worship," Noam Zohar has shown that avodah zarah also refers to the image being worshiped. ${ }^{9}$ Biblical Hebrew has several words for idols or foreign gods, but the Sages do not generally use those. Instead they use this collocation deriving from ritual ideas. For this reason, I use the term "worship of avodah zarah" rather than the English (and largely Christian) term "idolatry," which has connotations that are not present in rabbinic usage.

The Tannaitic Sages define practices that qualify as one as a worshipper of avodah zarah in m. Sanh. 7:6. ${ }^{10}$ This paragraph contains two lists of ritual activities, but only one of these lists contains activities that count as the worship of avodah zarah. The other activities simply break a negative commandment. The difference between what $\mathrm{m}$. Sanhedrin considers to be the worship of avodah zarah and what it does not is that it is ritual activities that are part of the Temple cult that make one liable for the biblically prescribed punishment of stoning. The worship of avodah zarah is a crime of sacrilege, understood both as a crime against the covenant and the misuse of the sacred.

\section{Ritual, Temple and Sacrilege}

The universality of the Tannaitic conception of ritual plays into the two primary points underscoring the Tannaitic conception of ritual. The first of these is that the Sages do not have separate categories of idol worship and acceptable ritual. In fact, the difficulty in non-Jewish ritual or idol worship

7 Cohn, Memory, 91-118.

8 The existence of the Noahide laws presents another example of the Tannaitic assumptions about the universality of their system. In fact, worshiping gods besides the God of Israel constituted a breach of the Noahide laws. See Tosefta Avodah Zarah 8.

9 See Noam Zohar, "Avodah Zarah and Its Annulment” (Hebrew), Sidra 17 (2001-2002) 64-77.

10 Under the influence of Christian censorship, "the one who worships avodah zarah" was changed to avodat kokavim u-mazalim, the worship of the stars and planets. It is also substituted for goyim, or Gentiles. The phrase avodah zarah is original, however. See the discussion in Elmslie, Mishna on Idolatry, 2, note on goyim. 
was not that it was something wholly different from Jewish ritual, but rather that it was all too familiar. Sacrifices, libations and incense offerings were activities that would have been found in both the cult practiced at the Jerusalem Temple and the other cultures which surrounded them.

In order to properly define their boundaries, the Sages deployed another biblical and legal category. In Leviticus, one of the many technical terms taken up by the biblical authors and editors is maial, a word that can be translated as "sacrilege." ${ }^{11}$ Jacob Milgrom notes that this kind of forbidden activity falls into "two major categories: the sacrilege against sancta and the violation of the covenant oath."12 The Sages pick up on the two connections in the Tannaitic commentary on Leviticus, Sifra, noting initially that "There is no sacrilege (meilah) except changing (that is to say, the changing of one's loyalty)." ${ }^{\prime 3}$ In support of this statement, the Sages cite 1 Chron 5:25 and Num 5:12. The Chronicles verse is part of the Chronicler's history of the Northern Kingdom of Israel, and states, "but they committed sacrilege $\left(m a^{c} a l\right)$ against the God of their fathers, and went astray ${ }^{14}$ with the gods of the peoples of the land, whom God had destroyed on their behalf." The sacrilege of the Northern Kingdom is expressly connected with their breaking of covenant loyalty, and their worship of gods apart from the God of Israel. The passage in Numbers connects $m a^{c} a l$ with adultery and sexual fidelity in marriage, highlighting once again the notion idea that macal and mecilah are transgressions against covenant loyalty. ${ }^{15}$

The examples given in the Mishnaic law of meilah primarily govern physical items and the monetary benefit and gain that come from them. The conceptual notion behind meilah goes much deeper than that, however. The idea that Temple property is the property of the divinity, and the inappropriate use of it is a crime, goes back to the Bible and the broader ancient Near East. ${ }^{16}$ Leviticus speaks in a number of places of food that is

11 See the discussion in Jacob Milgrom, Leviticus 1-16 (New York: Doubleday, 1991) 345-356. L Koehler and W. Baumgartner, Hebrew and Aramaic Lexicon of the Old Testament (HALOT) suggests a meaning of "disloyalty, infidelity" (613) while Brown, Driver, Briggs Hebrew and English Lexicon (BDB) puts forward "act unfaithfully, treacherously," with a note that this is a "priestly word" (591).

12 Milgrom, Leviticus, 346.

13 Sifra Dibura Dehoba 11, 1.

14 Hebrew zanah, a word that has strong sexual connotations, and refers to Israel/Judah's straying from their covenant loyalty. For discussion of this term, see Irene E. Reigner, Vanishing Hebrew Harlot (New York: Peter Lang Publishing, 2009).

15 For marriage as covenant in the Hebrew Bible, see Gordon P. Hugenberger, Marriage as a Covenant (Leiden: Brill, 1994; repub. Wipf and Stock, 2014).

16 One of the very earliest laws is in the Code of Hammurabi (1792-1750 BCE) $\$ 6$ : "Should a person steal the property of a god or palace, that person will be put to death." 
the priests' prerogative to eat, because it was consecrated and set apart (as in Lev 7:28-34). The idea of the misuse of Temple materials was also part of Roman conceptions, and so was an idea present in the world in which the Tannaitic Sages lived. ${ }^{17}$

\section{Ritual and Foreign Ritual}

It is common now in English to refer to any ritual or religious activity addressed to a being other than the God of Israel as idolatry. ${ }^{18}$ This word is somewhat unsatisfactory, however, because it carries with it certain connotative baggage, and it is not how the Tannaitic Sages understood nonJewish ritual activity. The discourse of the Tannaitic Sages on non-Jewish ritual is based on their conceptions of ritually generally, which derived from the Jerusalem Temple.

The collocation avodah zarah, does not appear in the Bible, although its constituent parts do. Avodah derives from a Hebrew root meaning "to serve" and carries the primary meaning of "work." ${ }^{19}$ This is how the Exodus account uses this term, describing the forced labor that the Egyptians put on the Israelites (Exod 1:14), and "work" is most common meaning of avodah throughout the Hebrew Bible. ${ }^{20}$ There are, however, places where avodah carries a ritual meaning. ${ }^{21}$ Generally speaking, in these contexts, the phrase refers to the ritual service at the Israelite/Judahite Tabernacle or Temple. The commandment to keep the Feast of Unleavened Bread is referred to as avodah in Exod 13:5: "And it will be, when the Lord brings you to the land

In addition, there were materials that belonged to the gods and so were off-limits, not because they were abominations, but because they were divine possessions. See M. J. Geller, “Taboo in Mesopotamia," Journal of Cuneiform Studies 42 (1990) 105-117, esp. $108-111$.

17 Eli Edward Burriss, "Misuse of Sacred Things at Rome," Classical Weekly 22 (1929) 105-10. The Roman term for this was sacrilege, deriving from sacer "sacred" and legere "to steal." For another ancient source that seems to connect foreign worship and sacrilege, see Rom 2:22 in the New Testament.

18 This process is contextualized in Joan-Pau Rubiés, “Theology, Ethnography, and the Historicization of Idolatry," Journal of the History of Ideas 67 (2006) 571-598.

19 HALOT, 776-777.

20 See, for example, Gen 29:27, 30:26; Ps 104:14, 23; Isa 14:3; Ezek 29:18.

21 The change in meaning from "work" to "ritual work" in the Hebrew Bible is given diachronic significance for the dating of the $\mathrm{P}$ material by Milgrom in Leviticus, 8 . Milgrom also notes that the ritual meaning of avodah still derives from its original meaning, i. e., ritual as work. There does seem to be a difference between the use of avodah in Leviticus and the use of avodah in Chronicles. Numbers, being largely P, uses avodah in a similar manner to Leviticus. 
of the Canaanites, the Hittites, the Amorites, the Hivites and the Jebusites, which he swore to your fathers to give to you - a land flowing with milk and honey - that you will work this ritual in this month."22

By the time of the composition of Chronicles, the term avodah still often refers to the work of the Levites, but this work has a ritual and liturgical function, as opposed to the primary work of carrying and moving the sacred materials as seen in Leviticus and Numbers. ${ }^{23}$ It also carries in these sections a general meaning of ritual of the Temple of Yahweh. Thus, 1 Chron 28:13 speaks of the "ritual vessels" (klei avodat beit YHVH) and 1 Chron 23:24 grants to the Levites part in "doing the work of the ritual of the house of Yahweh" (oseh hamel'acha la'avodat beit YHVH). ${ }^{24}$

The other half of the collocation, zarah, is an adjective referring to the type of ritual. This word zarah refers to strangeness or foreignness. ${ }^{25} \mathrm{In}$ Lev 10:1-2, Nadab and Abihu, the sons of Aaron, are destroyed by God for offering "strange fire" (esh zar). The biblical text gives no further meaning or explanation of how this incense-burning is different or displeasing to God. ${ }^{26}$ The word is also used in what is primarily a term of sexual opprobrium in the book of Proverbs, where several proverbs warn against a "strange woman."27 In addition, Ps 44:20 [21] speaks of praying to a "strange god," with a clear contextual meaning of a god who is not Yahweh. All of these uses probably had play in the coining of the post-biblical designation of non-Jewish worship as avodah zarah. In their monograph on the conceptual notion of idolatry in Judaism, therefore, Moshe Halbertal and Avishai Margalit note that the usage of the root for strangeness can be construed two ways: "One is the strangeness of the object toward which the worship is directed, not the 'proper' God, but other gods. The other refers

22 For convenience, all Hebrew sources come from Sefaria.org, unless otherwise noted. For the Mishnah, the Bialik Institute edition, with commentary by Hanoch Albeck, was also checked. All translations are the author's.

231 Chron 23:23-32. See Milgrom, Leviticus, 8.

24 A variation on this phrase also appears in 1 Chron 28:13.

25 HALOT, 279; G. Johannes Botterweck and Helmer Ringgren, eds., Theological Dictionary of the Old Testament, vol. 4, trans. David C. Green (Grand Rapids: Eerdmans, 1980) $52-8$.

26 The similarity between the names of these two sons of Aaron and the son of Jeroboam I has led some biblical scholars to suggest, probably correctly, that at least part of what is going on here is a polemic against the shrines of the Northern Kingdom, set up by Jeroboam I. See Moses Aberbach and Leivy Simolar, "Aaron, Jeroboam, and the Golden Calves," Journal of Biblical Literature 86 (1967) 129-40. The use of the word $z r$ would then underscore both the foreignness and the familiarity of the Northern Yahweh cult to the primarily Southern, Judahite authors of most of the Hebrew Bible. 27 See, for example, Prov 2:16-20 and 5:1-23; Botterweck and Ringgren, TDOT, 56-57. 
to the method of worship." 28 Thus, both the incense offering and the deity to whom it is offered may be "strange." This is a key point for understanding how the Mishnah and Tosefta are discussing foreign ritual, as the Tannaitic Sages are concerned about both kinds of "strangeness."

As in biblical Hebrew, in Mishnaic Hebrew avodah often has a meaning of "work" or "manual labor." ${ }^{29}$ It also carries a secondary meaning referring to the ritual in the Jerusalem Temple, as in m. Yoma 3:3: "No one enters the Temple court for the ritual service (avodah), even if ritually pure, until he immerses." In mishnaic literature, the collocation avodah zarah is the most common usage of the word avodah. When paired with zarah, it only refers to ritual, and always non-Jewish ritual. Not everything, however, which we would characterize as avodah zarah or idolatry, such as many of the socalled customs of the Amorites or the passing of seed through the fire to Molech, is so characterized in Tannaitic literature. Thus this article does not translate avodah zarah as "idolatry," because the ancient concept is not the same as our modern notion.

\section{Avodah Zarah and the Temple}

The connection between the Temple, covenant loyalty and the Sages' definition of ritual is discernible in m. Sanh. 7:6, which is the nearest the Tannaitic sources get to actually defining the worship of avodah zarah. This chapter is concerned with punishment under the law of Moses. According to Deut 17:2-6, the worship of other gods made one liable for death by stoning. It was therefore incumbent to clarify what activities qualified as the worship of other gods. M. Sanh. 7:6 lays out a number of forbidden activities: The one who worships avodah zarah is (a) the one who serves; (b) the one who sacrifices; (c) the one who burns incense; (d) the one who pours out libations; (e) the one who prostrates; (f) the one who receives it as his god; and (g) the one who says to it: You are my God.

Each of these activities was part of the temple cult as expressed in the Mishnah and as described in the Hebrew Bible. The following list provides examples (representative, rather than exhaustive):

28 Moshe Halbertal and Avishai Margalit, Idolatry, trans. Naomi Goldblum (Cambridge: Harvard University Press, 1994) 3.

29 Marcus Jastrow, Dictionary of Targumim, Talmud and Midrashic Literature (New York: G. Putnam and Sons, 1926) 1036. 
a. Service: m. Yoma 3:3: "No one should enter the Temple Court for the Service, except they are pure"; Exod 23:25: "And you will serve Yahweh, your God, and he will bless your bread and your water." ${ }^{30}$

b. Sacrifice: m. Zebah. 4:6: "A sacrifice must be sacrificed with 6 things in mind: the sacrifice, the sacrificer, God, ${ }^{31}$ the fires, the smell, and the sweet savor";

Exod 20:24: "And you will make for me an earthen altar, and you will sacrifice upon it your whole burnt offerings and your well-being offerings, your flocks and your herds." 32

c. Incense: m. Yoma 1:2: "All seven days he will sprinkle the blood, and offer the incense, and trim the lamps"; Exod 30:8: "And when Aaron shall light the lamps in the evening, he will offer incense upon it, as a perpetual incense offering for your generations." 33

d. Libations: m. Sheqal. 7:5: "At first they would extract pledges from anyone who found (an animal) until they would bring its libation offering"; Exod 29:40: "The tenth of a measure of fine flour with the fourth of a hin of fine oil, and the fourth of a hin of wine for a libation offering."

e. Prostration: $\mathrm{m}$. Yoma 6:2: "And when the priests and the people standing in the courtyard heard the Explicit Name come forth from the mouth of the priest, they would bend their knee, bow down, and fall on their faces"; Exod 33:10: "And all the people saw the pillar of the cloud standing at the door of the tent, and all the people stood up and bowed down, every man at the door of his tent."

In addition to being part of the Temple cult, these activities were common in the world surrounding the Tannaitic Sages. This speaks to one of the crucial points to understand about the Tannaitic conception of ritual: they were embedded in a Greco-Roman world and established their categories of ritual both in continuity with and in resistance against the broader Greco-Roman notions. Bruce Lincoln posits that societies use both force and discourse in the process of defining and constructing their societies. ${ }^{35}$ The Sages of the Mishnah lived in a world of Roman Imperial control and deployed a variety

30 See also Num 18:7, 1 Sam 12:14-24.

31 Lit. "the Name".

32 See also Exod 3:18, 5:3; Lev 1:9ff.

33 See also Lev 4:7, and especially Lev 10:1, where Nadab and Abihu offer their "strange fire" with incense; Menahem Haran, "Uses of Incense in the Ancient Israelite Ritual," Vetus Testamentum 10 (1960) 113-29.

34 A hin is a unit of liquid measurement which is roughly equal to 12 liters.

35 Bruce Lincoln, Discourse and the Construction of Society (Oxford: Oxford University Press, 1992) 3-5. 
of means to define their society. ${ }^{36}$ Some ancient Jews attempted to deploy force during the Jewish revolts with disastrous result. The literature of the Sages represents the efforts of the Sages to deploy discourse. In many ways, the Tannaitic discourse on non-Jewish ritual was a discourse built around defining the boundaries of a ritual that was all too similar to that of the Sages.

Naomi Janowitz suggests the possibility that that Jewish constructions of idolatry and image worship may even have come from the dominant paradigm of the Greco-Roman world. ${ }^{37}$ This serves as a reminder of the complexities that go into understanding the Tannaitic discourse on avodah zarah and non-Jewish ritual practices. On the one hand, the whole endeavor is necessitated by Exod 20:3-5 and the command to "have no other gods." On the other hand, what "other gods" meant in the Sages' environment would have been different from that in the original biblical context. The Sages are taking notions from the Bible and experiences from their own world, and combining them in order to articulate what it means to worship non-Jewish gods. This is significant because it highlights that, for the Sages, the problem with foreign ritual was not that it was something wholly different, but rather that it was something all too familiar. In fact, the Roman historian, Tacitus, explicitly connects Judaism to worship of the Roman god Liber Pater: ${ }^{38}$ "From the fact ... that their priests used to chant to the music of flutes and cymbals, and to wear garlands of ivy, and that a golden vine was found in the temple, some have thought that they worshiped Liber Pater, the conqueror of the East." ${ }^{39}$ Like sacrifice, the burning of incense and the other ritual activities mentioned in Sanh. 7:7, music was a ritual category which was shared by Judaism and the surrounding world, so much so that some non-Jews considered the similarities sufficient to make a connection between Judaism and a pagan cult. ${ }^{40}$ The rabbinic conception of ritual was a comparison of like-types, as noted, but this comparison went both ways.

36 See Mireille Hadas-Lebel, Jerusalem against Rome (Leuven: Peeters, 2006), esp. 7-35.

37 Naomi Janowitz, "Good Jews Don't," History of Religions (2007) 239-52.

38 Liber Pater was the Roman god of viticulture, associated with Dionysos and Bacchus. J.A. North, "Liber Pater," Oxford Classical Dictionary, ed. Simon Hornblower and Antony Spaworth (Oxford, Oxford University Press, 2005) (www.oxfordreference.com/ view/10.1093/acref/9780198606413.001.0001/acref-9780198606413-e-3679?rskey= iXY3Qd\&result=2).

39 Tacitus, History 5:5, trans. Alfred John Church.

40 The connection made in Tacitus between Liber Pater and the God of Israel finds odd support in the writings of Josephus, where he calls the palm branches used at Sukkot "thyrsus," the fennel branch closely associated with the worship of Dionysus; Josephus, Antiquities of the Jews 13.372. On the connection between Dionysus and the God of Israel, see Joseph Geiger, "Plutarch, Dionysus, and the God of the Jews Revisited," in 
The list from m. Sanh. 7:6 points, therefore, to close connection between the rabbinic conception of ritual and the rabbis' observations of the rituals from the surrounding world. The first item on the list is sacrifice, which is fitting, because it is the ritual par excellence in the ancient world; in its various forms, it was at the core of ancient religion. ${ }^{41}$ The next item on the list is the burning of incense. ${ }^{42}$ Incense is, in many ways, part of a regional conception of ritual, one that is naturally brought about by the heat of the Mediterranean region. ${ }^{43}$ Incense burning was done not only in Israelite religion and in the Jerusalem temple cult, but was also attested in Egypt, in Mesopotamia and in Syria and Phoenicia. ${ }^{44}$ It was also included as part of Greek and Roman cults, and is well-attested both iconographically and archaeologically. ${ }^{45}$

The following list gives examples of all of these activities in ancient, nonJewish contexts: ${ }^{46}$

a. Service: Greek: latreia; Egyptian: ir $n^{47}$

b. Sacrifice: ${ }^{48}$ Greece: "It is usual to sacrifice to the god any animal except the goat." ${ }^{49}$

Gods, Daimones, Rituals, Myths and History of Religions in Plutarch's Works, ed. L. Van der Stockt et al. (Logan: International Plutarch Society, 2010) 211-220.

41 Robert Parker, On Greek Religion (Ithaca, New York: Cornell University Press, 2011) 124.

42 For a discussion of this in biblical times, both in Israel/Judah and in the surrounding nations, see Kjeld Nielsen, Incense in Ancient Israel (Leiden: Brill, 1986); also Mervyn D. Fowler, "BA’s Guide to Artifacts," Biblical Archaeologist 47 (1984) 183-6.

43 Nielsen, Incense, $\mathrm{v}$.

44 Nielsen, Incense, 11-17.

45 Erika Simon and Haiganuch Sarian, "Rauchopfer," in Thesaurus Cultus et Rituum Antiquorum, vol. 1 (Los Angeles: Getty Publications, 2004) 255-68, 255; David Gordon Mittem, "Two New Bronze Objects in the McDaniel Collection," Studies in Classical Philology 69 (1965) 163-7.

46 Many of these examples were culled from the Thesaurus Cultus et Rituum Antiquorum (ThesCRA), ed. J. C. Balty et al. (Los Angeles: J. Paul Getty Museum, 2004-2012).

47 Raymond O. Faulkner, Concise Dictionary of Middle Egyptian (Oxford: Griffith Institute) 27. This collocation derives from the word iri, which can have the sense of "to make or to do," bringing it, conceptually, in line with the Hebrew and Greek idea of worship as a service. John D. Ray notes "There is no specific word for 'ritual' in the Egyptian language; they are variously referred to as ir ht 'doing things', irw, 'things done, or $n t-3$, 'regular procedure (lit., that pertaining to prescription)"'; "Cults," in Ancient Gods Speak, ed. Donald B. Redford (Oxford: Oxford University Press, 2002) 61-91, 63 .

48 For the Greek view of Egyptian animal sacrifice, see also Herodotus, History 2:38-40.

49 Pausanias, Description, Phocis 32:12. 
c. Incense: Greece: "They sacrifice in an ancient manner, for they burn on the altars incense with wheat that has been kneaded with honey" ${ }^{20}$; Egypt: "[Spell for] Placing the incense-bowl on the censor arm: Words to be said: Hail to you, incense bowl of [...]".51

d. Libation: ${ }^{52}$ Greece: "No other man would drink the shining wine from its glowing depths; neither would Achilles pour the wine to any other god, none but Father Zeus." ${ }^{\text {53; }}$ Egypt: image in Temple of Seti I in Abydos, Chapel of Osiris, North Wall, Eastern Section. ${ }^{54}$

e. Prostration: Greece: "When the Lacedaemonians saw them they bowed down $n^{55}$ and prayed" ${ }^{26}$; Egypt: "I have prostrated (myself) through fear of you." 57

Many of the activities punishable in the Mishnah as the worship of avodah zarah, such as the offering of sacrifice and the burning of incense, were, during the period of the Second Temple, activities considered to be only appropriate within the walls of the Temple. The Tannaitic discourse on non-Jewish ritual represents the attempts of the Sages to grapple with the presence of these activities in non-Jewish ritual contexts. The act of sacrifice must not, in and of itself, be an incorrect action, because God himself sets forth a detailed system of sacrificial law in the Torah. ${ }^{58}$ Similarly, libation must not of itself be wrong, because the Torah contains laws about how to use libations in the worship of God. "The strangeness of the object toward which the worship is directed, not the 'proper' God, but other gods." 59

From the Tannaitic perspective, activities that were reserved for the Temple should remain the preserve of the Temple. ${ }^{60}$ Part of the general com-

50 Pausanias, Description, Elis I 15:10.

51 "Daily Ritual of the Temple of Amun-Re At Karnak," trans. Robert K. Ritner, in Context of Scripture 1.34, ed. William Hallo (Leiden: Brill, 1997) 55-56; William H. Peck, "A Ramesside Ruler Offers Incense," Journal of Near Eastern Studies 31 (1972) 11-15. For a discussion of the "incense bowl on the censor arm," see H. G. Fischer, "Evolution of the Armlike Censer," Journal of the American Research Center in Egypt 2 (1963) 28-34.

52 Fritz Graf, "Milch, Honig und Wein," in Perenitas: Studi in onore de Angelo Brelich, ed. U. Bianchi et al. (Rome: Ediz. dell'Ateneo, 1980) 209-21.

53 Homer, Iliad 16, 225-229, trans. Robert Fagles (New York: Penguin Books, 1990).

54 Alan H. Gardiner, ed., Temple of King Sethos I at Abydos, vol. 1 (London and Chicago: Egypt Exploration Society and University of Chicago Press, 1933) Pl. 4.

55 Greek prosekunoun.

56 Pausanias, Description, Messenia 27:2.

57 Ritner, "Daily Temple Ritual," 56.

58 See Neusner, "Map," 103-127.

59 Halbertal and Margalit, Idolatry, 3.

60 In addition to me ilah, this is the same logic that occasions the discussion of non-sacral slaughter in the tractate of Hullin. 
plex of ritual practice in the ancient world was the constant play between cult inside formal shrines and cultic practices outside of the shrine. In discussing magic, David Frankfurter has noted that oftentimes magical rituals were cultic rituals appropriated and used outside the cult for different purposes. ${ }^{61}$ Examples of this proliferate in the Greek magical papyri, where syncretic spells such as Mithras Liturgy abound. ${ }^{62}$ This kind of situation was unacceptable to the Sages of the Mishnah - in many ways the laws surrounding avodah zarah represent the attempts of the Sages to police the boundaries of what constituted acceptable usage of Temple activities. One of the most recognizable examples of this is the regulation that the name of God not be pronounced outside of the Temple. This is evident in $\mathrm{m}$. Sotah 7:6, where in discussing the Priestly Blessing the Sages assert "in the Temple he said the name as written, in the provinces with a euphemism."

M. Sanh. 7:5, which regulates the questioning of blasphemers, operates under the assumption that the name was generally known, but was forbidden to say. During most of the questioning, the witnesses used a euphemism (Hebrew kinuy). At the very end of the questioning, the court sent the audience out and asked the chief witness to state what he had heard - after this, the rest of witnesses consent that this is what they heard. This indicates that the witnesses and the court could recognize the divine name, but they went out of their way to mitigate the number of times it was pronounced. The Sages understood the divine Name as sacred, in the original meaning of related to the Temple, and so regulated its usage outside of those contexts.

Drawing on the biblical record and deploying it in their own circumstances, the Sages dealt with the worship of non-Israelite gods in a way that highlighted covenant loyalty. The worship of avodah zarah represents the changing of covenant loyalty, as well as changing the use of Temple objects and rituals to non-sacred purposes. Because of this, avodah and ritual were deeply rooted in the rites of the Temple, and thus the Tannaitic discourse on the rituals of non-Jews must also be based upon the rites of the Temple. To perform these activities outside their prescribed sacred situations turns them into meilah, and thus makes them punishable as the worship of avodah zarah - both a violation of the covenant oath and sacrilege against sancta.

61 David Frankfurter, "Dynamics of Ritual Expertise in Antiquity and Beyond," in Magic and Ritual in the Ancient World, ed. Paul Allen Mirecki and Marvin W. Meyer (Leiden: Brill, 2001) 159-78.

62 Hans Dieter Betz, ed., Greek Magical Papyri in Translation (Chicago: University of Chicago Press, 1992) 48-54. In some cases, Jewish conceptions and angelology made their way into Greco-Roman magical practice; see Gideon Bohak, Ancient Jewish Magic (Cambridge: Cambridge University Press, 2008) 196-201. 
The recognition that the Sages' discourse on the worship of avodah zarah is firmly tied to the Temple, its accoutrements and rituals, and to the covenant loyalty to God that it represented explains one of the more difficult passages in Mishnah's discussion of idolatry and foreign worship. Immediately following the list of activities that qualify as the worship of avodah zarah, Sanh. 7:6 has another list of activities that do not qualify as the worship of avodah zarah: "but the one who embraces, the one who kisses, the one who tidies up, the one who washes, the one who anoints, the one who dresses or the one who shoes transgresses a negative commandment."

This list is juxtaposed with the actual worship of avodah zarah through the use of the adversative "but" (aval). These misdeeds are not stoning offences, because they are not in the same category as the one who worships avodah zarah. This, of course, leads to the question of the difference between the two different lists of ritual action. The key difference between activities that constitute the worship of avodah zarah and those that (only) transgress a negative commandment is that the latter are all things one does to an image. The very activities we might most naturally consider to be "idolatry" - those that involve interacting with an "idol", or image - are expressly identified as not constituting the worship of avodah zarah.

The key issue in determining what qualified as worship of avodah zarah was whether the activity was something that properly belonged to the Temple and the worship of the God of Israel. Because the Temple cult had no image, as such, it was not possible for actions pertaining to an image to be found in the Temple cult, and so activities such as washing or dressing an image do not count as the worship of avodah zarah. Of the two lists of prohibited activity in $\mathrm{m}$. Sanh. 7:6, even given the biblically mandated hostility to images, ${ }^{63}$ only those activities that were part of the Temple counted as the worship of avodah zarah, and so only these were liable for the death penalty. This means that although the laws against foreign worship are based in the prohibition in Exodus 20 or Deuteronomy 17, the rules for determining what the worship of avodah zarah looks like are firmly based around the laws of sacrilege. This passage, therefore, situates the Sages' discourse on the worship of avodah zarah as discourse that is situated in concepts of meilah, both in terms of the misuse of sacred things and in terms of the breach of covenant loyalty.

63 Indeed, m. Avodah Zarah has a large section devoted to regulation of Jewish interaction with foreign divine images. See Urbach, "Rabbinical Laws,"149-65 and 229-54; Zohar, "Avodah Zarah," 64-77; Moti Arad, "Ye Shall Surely Destroy all the Places, Wherein the Nations That Ye are to Dispossess Served Their Gods"' (Hebrew), Oqimta 1 (2013) 25-69. 


\section{Molech: A Test Case}

The forbidden practice of passing a child through the fire to Molech represents another instance in which an activity that seems like a clear example of foreign ritual is not so construed by the Sages. Because of this, it serves as an instructive example of how the Tannaitic basing of their ritual notions in the Temple and its cult played out.

Immediately after defining and delimitating the practices that count as worshiping avodah zarah, m. Sanh. 7:8 addresses the biblical practice of passing one's children through the fire to Molech:

As for the one who passes his seed to Molech, he is not liable until he dedicates to Molech and he passes him through the fire. [If] he dedicates to Molech, but does not pass through the fire, (or) if he passes through the fire, but does not dedicate to Molech, he is not liable, until he has (both) dedicated him to Molech and passed him through the fire.

This practice is forbidden in Lev 18:21: "And you will not give of your seed to pass through to Molech." In this verse there is no mention of fire, although there are other places where fire is mentioned. ${ }^{64}$ Scholarly opinion is divided on the topic of what the biblical phrase "passing one's seed through the fire to Molech" actually entails. ${ }^{65}$ Some scholars have connected this ritual to the tophet condemned in the prophets, or to the Phoenician molk sacrifices, linking this practice to some form of Israelite or Canaanite human sacrifice. ${ }^{66}$ Others have suggested that it refers to a dedicatory

$642 \mathrm{Kgs} 23: 10$ is the only place in the Hebrew Bible where the divine name Molech appears in conjunction with a specific reference to fire. Generally speaking, if Molech is mentioned, fire is not, and vice versa. Compare, for example, Lev 18:21 to $2 \mathrm{Kgs}$ 21:6. This may be why the Sages identify offering to Molech and passing through the fire as different ritual acts.

65 See overview in Geza Vermes, "Leviticus 18:21 in Ancient Jewish Bible Exegesis," in Studies in Aggadah, Targum and Jewish Liturgy in Memory of Joseph Heinemann, ed. Jakob J. Petuchowski and Ezra Fleischer (Jerusalem: Magnes, 1981) 108-24, 109. Also Moshe Weinfeld and S. David Sperling. "Moloch, Cult of," in Encyclopedia Judaica, vol. 14 (Detroit: Macmillan Reference, 2007) 427-9; G. C. Heider, "Molech," Dictionary of Deities and Demons in the Bible, ed. K. van der Toorn, B. Becking and P.W. van der Horst (Leiden: Brill, 1995) 581-5; John Day, Molech (Cambridge: Cambridge University Publications, 1985). Thomas Hieke does not even think that it has ritual connotations, but refers to avoiding Persian military service; see "Das Verbot der Übergabe von Nachkommen an den 'Molech' in Lev 18 und 20," Velt des Orients 41 (2011) 147-67.

66 First suggested in Otto Eissfeldt, Molk als Opferbegriff im Punischen und Hebräischen und das Ende des Gottes Moloch (Halle: M. Niemeyer, 1935); Morton Smith defends the idea that this refers to the practice of human sacrifice in "A Note on Burning Babies," JAOS 95 (1975) 477-9. 
ritual offered up to a god. ${ }^{67}$ Its placement in the Holiness Code, embedded between two sections on sexual behavior, suggests that in the Bible it may have been associated with sexual misconduct, rather than with the cultic practices discussed later on in that chapter.

The difficulty modern scholars face in pinning down the nature of the practice of passing through the fire to Molech highlights the similar problem the Tannaitic Sages dealt with. For them, Molech was worshiped both through an act of dedication and a cryptic ritual act of "passing through the fire." 68 The text of $\mathrm{m}$. Sanh. 7:8 is clear on one count, however: one is only guilty of "giving seed to Molech" if one both dedicates it to Molech and also causes it to pass through the fire. ${ }^{69}$

As with the various activities which were performed on a specific image, the ritual of passing children through the fire to Molech could not be part of the ritual of the Jerusalem temple, and since it had no part in the Jerusalem Temple cult, it could not be the considered worship of avodah zarah. ${ }^{70}$ Thus the Tannaitic Sages did not put the passing through the fire to Molech into the same legal category as worship of avodah zarah. ${ }^{71}$

67 Ziony Zevit, Religions of Ancient Israel (New York: Continuum, 2001) 469. He then connects this with ritual purification by fire of vessels, such as in Num 31:23: "Everything that can stand the fire, you will pass through the fire, and it will be clean." The verb for passing through the fire in Numbers is the same verb that is often found in the collocation referring to Molech. In connection with passing things through the fire, in order for them to come clean, see m. Avod. Zar. 5:12. Also N. H. Snaith, "Cult of Molech," Vetus Testamentum 16 (1966) 123-4.

68 That this collocation and ritual practice are what are important to the Sages may be seen by the fact that the divine name Molech does not appear by itself at all in Tannaitic literature, but appears dozens of times in the Mishnah and Tannaitic midrashim with the preposition lamed in connection with this ritual practice.

69 Vermes observes that this has the effect of rendering "law prohibiting the worship of [Molech] completely redundant"; Vermes, "Leviticus," 118.

70 It may be that the ritual actions entailed here could be actionable under other laws, of course. It is difficult to see any circumstance where dedicating seed to Molech would be approved of by the Tannaitic Sages, or not be considered the worship of a non-Jewish god.

71 B. Sanh. 64a explicitly states that "passing through the fire to Molech does not constitute worshiping avodah zarah," in a saying attributed to R. Abin, a Palestinian Amora. If this can be related back to the Mishnaic period, it has significant implications for the idea of what is actually going on in the minds of the Sages vis-à-vis passing through the fire to Molech. 


\section{Conclusion}

It is clear from their own discourse that the Sages saw a complex relationship between their own rituals and those of the various nations that surrounded them. The worship of avodah zarah, as the Sages called idolatry, was a thorny practice because those activities that were at the core of nonJewish religious practice, such as sacrifice, were also at the core of Jewish religious practice. The Sages' discourse on non-Jewish ritual and religious practice therefore had to find a place to explain what did and did not constitute plausible grounds for the sin of worshipping other gods. That plausible ground was found in the Jerusalem cult and laws of sacrilege and meilah. As the Sages articulated in Sifra, sacrilege consisted both of changing sacred things to non-sacred usages and changing the covenant loyalty to someone or something else. The worship of avodah zarah was both.

Thus, the ritual actions that are condemned as the worship of avodah zarah are only those that were also performed to the God of Israel in the Jerusalem Temple, because only those counted as sacrilege. The worship of avodah zarah is not condemned, therefore, because of the inherent differences between non-Jewish ritual and Jewish ritual. Instead, it was the very similarities between the two that pushed the Sages' conceptions of these two rituals. For them, part of what makes worshiping avodah zarah so heinous is that it is part of the broader concept of avodah, and so also comes under the conceptual category of meilah. This means that although the rabbinic laws against the worship of avodah zarah are based on the biblical prohibitions against worshiping other gods, the actual rules for how these laws are to be enacted are extrapolations of the laws against the misuse of Temple objects.

The Temple stood at the center of the Jewish religious, and especially ritual, world. It had unique elements, but its practices were not wholly unique in the ancient world. The Sages were aware of this, and from their perspective, the difficulty in the worship of avodah zarah was precisely that the rituals in the Temple were so similar to other, non-Jewish, rituals in the Roman world. The Tannaitic conception of the worship of avodah zarah thus derives from a system of cultural conceptions that were different from an idealized notion of idolatry, and was a comparison of like types. This necessitated creating a system for policing those places where there were differences. Instead of creating an essentialized definition of other rituals, the Sages turned to the laws of sacrilege, highlighting the nature of the crime as change to both the sacred to the profane and to covenant loyalty. This situated their discourse firmly in the Temple, while providing space 
for discussing both the differences and the similarities. Ultimately, the rules against the worship of avodah zarah represented a discourse on their own rituals and their own needs much more than it served as a comment on the rituals of non-Jews. 